\title{
PENGARUH KEPEMIMPINAN ISLAMI, KOMPENSASI FINANSIAL DAN MOTIVASI KERJA TERHADAP KINERJA DOSEN UNIVERSITAS DJUANDA BOGOR PROVINSI JAWA BARAT
}

\author{
Ismartaya $^{1} \&$ Meydia $^{2}$ \\ ${ }^{1}$ Program Studi Manajemen, Universitas Djuanda Bogor \\ ${ }^{2}$ Pusat Kajian Sumberdaya Pesisir dan Lautan, IPB University \\ Email: Ismartaya@unida.ac.id, meydia@pksplipb.or.id
}

\begin{abstract}
ABSTRAK
Penelitian ini bertujuan untuk menentukan hubungan antara kepemimpinan Islami, kompensasi finansial dan motivasi terhadap kinerja dosen di Universitas Djuanda Bogor. Responden adalah dosen Universitas Djuanda sebanyak 111 orang yang dipilih secara acak. Data dikumpulkan menggunakan instrumen dalam bentuk kuesioner. Instrumen dikalibrasi menggunakan validitas item dan koefisien keandalan. Data dianalisis menggunakan Structural Equation Modeling (SEM) dengan paket PLS Smart. Hasil penelitian menunjukkan bahwa: (1). Kepemimpinan Islami $\left(\mathrm{X}_{1}\right)$ secara signifikan mempengaruhi motivasi kerja $\left(\mathrm{X}_{3}\right)$. Hal ini didukung dengan nilai $\mathrm{t}$-statistic diatas 1,96 yaitu sebesar 3,653. (2). Kompensasi finansial $\left(X_{2}\right)$ tidak berpengaruh terhadap motivasi kerja $\left(X_{3}\right)$, hal ini ditunjukkan dengan nilai t-statistik sebesar 0,283. (3). Karena nilai t-statistic sebesar 0,793 dibawah t- tabel $(1,96)$, hal ini berarti bahwa kompensasi finansial $\left(\mathrm{X}_{2}\right)$ tidak mempengaruhi kinerja karyawan $(\mathrm{Y})$. (4). Kepemimpinan Islami $\left(\mathrm{X}_{1}\right)$ secara signifikan mempengaruhi kinerja dosen $(\mathrm{Y})$ dengan nilai t- statistic diatas t-tabel $(1,96)$ yaitu sebesar 2,624. (5). Motivasi Kerja $\left(\mathrm{X}_{3}\right)$ secara signifikan mempengaruhi Kinerja dosen $(\mathrm{Y})$ dengan nilai t- statistic 4,294. Motivasi kerja $\left(\mathrm{X}_{3}\right)$ secara langsung memiliki pengaruh positif yang signifikan pada kinerja dosen (Y). Temuan ini memiliki implikasi bahwa kompensasi finansial tidak mempengaruhi motivasi kerja dan kinerja dosen. Kepemimpinan Islami secara signifikan mempengaruhi motivasi kerja dan kinerja dosen.
\end{abstract}

Kata kunci: Kepemimpinan Islami, Kompensasi Finansial, Motivasi, Kinerja.

\section{ABSTRACT}

This study aims to determine the relationship between Islamic leadership, financial compensation and motivation on lecturer performance at Djuanda University, Bogor. The respondents were 111 lecturers at Djuanda University who were randomly selected. Data were collected using an instrument in the form of a questionnaire. The instrument was calibrated using item validity and reliability coefficients. Data were analyzed using Structural Equation Modeling (SEM) with the PLS Smart package. The results showed that: (1). Islamic Leadership $\left(X_{1}\right)$ significantly affected working motivation $\left(X_{3}\right)$. This was supported by the t-statistic value above 1.96, which was 3.653. (2). Financial compensation $\left(X_{2}\right)$ had no effect on work motivation $\left(X_{3}\right)$, this was indicated by the $t$ statistic value of 0.283. (3). because the t-statistic value was 0.793 below the t-table (1.96), which mean that financial compensation $\left(X_{2}\right)$ did not affect employee performance (Y). (4). Islamic leadership $\left(X_{1}\right)$ significantly affected on lecturer performance. $(Y)$ with the $t$-statistic value above the t-table (1.96) which is equal to 2.624. (5). Working motivation $\left(X_{3}\right)$ significantly affected on lecturer performance $(Y)$ with a t-statistic value of 4.294. Working motivation $\left(X_{3}\right)$ directly had a significant positive effect on lecturer performance $(Y)$. This finding implies that financial compensation does not affect on working motivation and lecturer performance. Islamic leadership significantly affects workmotivation and lecturer performance.

Keywords: Islamic Leadership, Financial Compensation, Motivation, Performance. 


\section{PENDAHULUAN}

Dalam era persaingan usaha yang semakin ketat, kinerja yang dimiliki karyawan dituntut untuk terus meningkat. Salah satu langkah untuk mempertahankan atau meningkatkan kinerja karyawan dapat dilakukan dengan mengevaluasi kinerja karyawan dan melakukan serangkaian perbaikan agar selalu meningkatkan kualitas karyawan tersebut sehingga perusahaan atau perguruan tinggi tumbuh dan unggul dalam persaingan global, atau minimal tetap dapat bertahan. Universitas Djuanda Bogor sejak tahun 2006 dan dengan terpilihnya Dr. H. Martin Roestamy, S.H, M.H sebagai Rektor dan di lanjutkan Dr. Ir. Dede Kardaya, M.Si telah mengikrarkan lembaga itu dengan sebutan "Kampus Bertauhid" sebagai konsekuensi logis dan realisasi dari visi dan misinya yang berbasis tauhid, kemudian pada tanggal 2010 dibentuknya sebuah lembaga yang menangani permasalahan kehidupan kampus bertauhid yang diberi nama "Lembaga Pengkajian dan Penerapan Tauhid" (LP2T) dengan diangkatnya Sdr. Drs. Amir Mahrudin, M.PdI sebagai Direkturnya pada tanggal 18 Maret 2010. Fungsi dan tugas lembaga itu pada prinsipnya menjalankan dakwah amar ma'ruf dan nahi munkar sebagai warisan para nabi dan rasul dalam rangka menegakkan "kalimat tauhid" di lingkungan universitas, baik pada aspek Tridarma Perguruan Tinggi.

Kepemimpinan adalah proses mempengaruhi kegiatan-kegiatan seseorang atau kelompok dalam usahanya mencapai tujuan di dalam suatu situasi tertentu. Berdasarkan defenisi tersebut, bahwa kepemimpinan terjadi apabila di dalam situasi tertentu seseorang mempengaruhi perilaku orang lain baik secara individu atau kelompok.

Ini terbukti Universitas Djuanda pada tahun 2018 UNIDA menduduki peringkat 66 se-Indonesia, sedangkan pada tahun 2019 UNIDA naik pada peringkat 60 dari 2.141 perguruan tinggi negeri dan swasta Non-Vokasi seIndonesia serta memperoleh peringkat 4 Perguruan Tinggi Swasta (PTS) terbaik dari 477 PTS LLDIKTI Wilayah IV Jawa Barat dan Banten. Berada di peringkat 60, UNIDA termasuk dalam klaster 2 bersama dengan 70 perguruan tinggi lainnya yang terdiri dari universitas negeri dan swasta. Dari tahun ke tahun Alhamdulillah UNIDA Bogor memperoleh peningkatan dalam Peringkat Klasterisasi Perguruan Tinggi non-vokasi se-Indonesia. Dalam kenaikan peringkat ini sebenarnya untuk percepat pencapaian visi UNIDA yaitu menjadi universitas riset yang menyatu dalam tauhid serta diakui oleh dunia, maka dari itu semua akademika UNIDA diwajibkan untuk selalu melaksanakan Pancadarma universitas yang diantaranya ciri khas UNIDA yaitu aktivitas ketauhidan itulah salah satu kepemimpinan Islami yang dierapkan diperguruan tinggi Universitas Djuanda Bogor. Seperti yang disampaikan oleh Dr. Ir. Dede Kardaya, M.Si. selaku Rektor UNIDA Bogor.

Sukses tidaknya dalam mencapai tujuan organisasi tergantung pada kemampuan pimpinan mempengaruhi bawahan dalam mengajak dan menyakinkan mereka dengan kepemimpinan Islami berdasarkan AlQur'an dan As-Sunnah, sehingga para bawahan ikut berpartisipasi terhadap apa yang telah dianjurkan dengan penuh semangat. Pemimpin adalah orang yang memberikan visi dan tujuan. Dan sejarah teori kepemimpinan menjelaskan bahwa kepemimpinan yang dicontohkan Islam adalah model terbaik. Model kepemimpinan yang disebut sebagai Prophetic Leadership yang dicontohkan junjungan kita nabi besar Muhammad SAW. Pemimpin umat yang merupakan faktor penentu dalam sukses atau tidaknya 
suatu organisasi sebab pemimpin Islami yang sukses itu mampu mengelola organisasinya untuk mengantisipasi dan sanggup membawa kepada tujuan organisasi yang ingin dicapai. Penelitian ini bertujuan untuk menganalisis pengaruh kepemimpinan Islami, kompensasi finansial dan motivasi kerja terhadap kinerja dosen pada Universitas Djuanda Bogor.

\section{TINJAUAN PUSTAKA}

Menurut Bastoni (2009), Hakikat Kepemimpinan Islam adalah agama yang komprehensif, ia tidak hanya mengatur cara manusia menyembah Tuhannya, tetapi juga mengatur segala sendi kehidupan. Mulai dari tata cara hidup bermasyarakat, menuntut ilmu, bahkan juga mengatur tata negara dan kepemimpinan.

Menurut Abdul Jawwad (2009), pemimpin dan kepemimpinan dalam Islam telah diatur dalam hukum syari'at Islam. Setiap manusia pasti menyandang predikat sebagai seorang pemimpin, baik dalam tingkatan tinggi misalnya presiden maupun dalam tingkatan yang paling rendah, yaitu pemimpin bagi diri sendiri. Setiap bentuk kepemimpinan perlu suatu keahlian. Kepemimpinan tidak bisa dijalankan hanya dengan kemampuan seadanya. Sebab, akan menimbulkan gejolak di antara anggota yang dipimpinnya. Dalam istilah lain pemimpin sering merujuk pengertian Ulil Amri atau pejabat adalah orang yang mendapat amanah untuk mengurus urusan orang lain dan Khadimul Umat (pelayan umat) dengan pengertian seorang pemimpin harus menempatkan diri pada posisi sebagai pelayan masyarakat.

Seperti yang telah dikutip oleh Hafidhuddin dan Tanjung (2003) dalam bukunya yang berjudul "Manajemen Syari'ah dalam Praktek", Syekh Muhammad Al-Mubaraq menyatakan ada 4 syarat seseorang untuk bisa menjadi pemimpin yaitu : 1 . Memiliki aqidah yang benar (Aqidah Salimah). 2. Memiliki ilmu pengetahuan dan wawasan yang luas. 3 . Memiliki akhlak yang mulia (Akhlaqul Karimah) 4. Memiliki kecakapan manajerial dan memahami ilmu-ilmu administrasi dan manajemen dalam urusan duniawi.

Kepemimpinan menurut Terry dalam Davis (1985) "Leadership is the relationship in which one person, or the leader, influences others to work togethet willingly on related tasks to attain that which the leader desires", kepemimpinan adalah proses mendorong dan membantu orang lain untuk bekerja dengan antusias guna mencapai tujuan.

Menurut Griffin dan Ronald (1998), kepemimpinan (leadership) adalah proses memotivasi orang lain untuk mau bekerja dalam rangka mencapai tujuan yang telah ditetapkan. William dan Patrick (1997) dalam membahas "Mutu Total dan Pembangunan Organisasi” mengemukakan bahwa kepemimpinan adalah suatu upaya merealisasikan tujuan perusahaan dengan memadukan kebutuhan para individu untuk terus tumbuh berkembang dengan tujuan organisasi. Perlu diketahui bahwa para individu merupakan anggota dari perusahaan.

Namun dalam perkembangannya, aplikasi kepemimpinan Islam saat ini terlihat semakin jauh dari harapan masyarakat. Para tokohnya terlihat dengan mudah kehilangan kendali atas terjadinya siklus konflik yang terus terjadi. Harapan masyarakat akan munculnya seorang tokoh muslim yang mampu dan bisa diterima oleh semua lapisan dalam mewujudkan Negara Kesatuan Republik Indonesia yang tercinta, kuat, sejahtera dan adil makmur nampaknya masih harus melalui jalan yang panjang. Tokoh pemimpin (imam) menjadi harapan dalam penciptaan masyarakat adil dan makmur 
sebagai salah satu tujuan terbentuknya Negara Republik Indonesia.

Imamah atau kepemimpinan Islam adalah konsep yang tercantum dalam $\mathrm{Al}$ Qur'an dan As-Sunnah, yang meliputi kehidupan manusia dari pribadi, berdua, keluarga bahkan sampai umat manusia atau kelompok. Konsep ini mencakup baik cara-cara memimpin maupun dipimpin demi terlaksananya ajaran Islam untuk menjamin kehidupan yang lebih baik di dunia maupun di akhirat sebagai tujuan akhirnya.

Dalam pandangan Islam, kepemimpinan merupakan amanah dan tanggung jawab yang tidak hanya dipertanggung jawabkan kepada anggotaanggota yang dipimpinnya, tetapi juga akan dipertanggung jawabkan dihadapan Allah SWT. Jadi, pertanggung jawaban kepemimpinan dalam Islam tidak hanya bersifat horizontal-formal sesama manusia saja, tetapi bersifat vertikal-moral, yakni tanggung jawab kepada Allah SWT di akhirat nanti. Kepemimpinan sebenarnya tidak semua mesti menyenangkan, tetapi merupakan tanggung jawab sekaligus amanah yang amat berat yang harus kita laksanakan dengan sebaik-baiknya. Allah SWT berfirman :

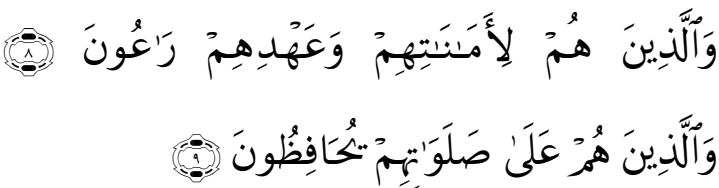

Artinya : dan orang-orang yang memelihara amanat-amanat (yang dipikulnya) dan janjinya. dan orangorang yang memelihara sembahyangnya. (QS.Al Mukminun 8-9)

Perlu diketahui seorang pemimpin harus bersifat amanah, sebab ia akan diserahi tanggung jawab. Jika pemimpin tidak mempunyai sifat amanah, tentu yang terjadi adalah penyalah gunaan jabatan dan wewenang untuk hal-hal yang kurang baik. Manusia diberi amanah Allah SWT untuk menjadi khalifah Allah SWT di muka bumi (QS. Al-Baqarah: 30). Khalifah bertugas merealisasikan misi sucinya sebagai pembawa rahmat bagi alam semesta.

Sabda Rasulullah SAW : "Setiap kamu adalah pemimpin dan tiap-tiap pemimpin akan dimintai pertanggung jawabannya". Manusia yang diberi amanah dapat memelihara amanah tersebut dan Allah SWT telah melengkapi manusia dengan kemampuan konsepsional.

Uraian di atas, dapat ditegaskan bahwa, kepemimpinan Islam adalah suatu proses atau kemampuan orang lain untuk mengarahkan dan memotivasi tingkah laku orang lain, serta ada usaha kerja sama dengan orang lain, sesuai dengan AlQur'an dan Hadis untuk mencapai tujuan yang diinginkan secara bersama.

Kompensasi adalah semua pendapatan yang berbentuk uang, barang langsung atau tidak langsung yang diterima karyawan sebagai imbalan atas jasa yang diberikan kepada perusahaan Hasibuan (2006). Handoko (2001) mengemukakan bahwa kompensasi penting bagi karyawan dan individu karena besarnya kompensasi mencerminkan ukuran nilai karya mereka diantara karyawan sendiri, keluarga dan masyarakat.

Menurut Simamora (2006) pada umumnya komponen kompensasi dapat dibagi menjadi kompensasi langsung (direct compensation) dan kompensasi tidak langsung (indirect compensation). Kompensasi finansial langsung (direct financial compensation) terdiri dari bayaran (pay) yang diperoleh seseorang dalam bentuk gaji, upah, bonus. Kompensasi finansial tidak langsung (indirect financial compensation) yang disebut dengan tunjangan meliputi semua imbalan finansial yang tidak tercakup dalam kompensasi langsung. Kompensasi 
non finansial (nonfinancial compensation) terdiri atas kepuasan kerja yang diperoleh seseorang dari pekerjaan itu sendiri atau dari lingkungan psikologis di mana orang itu bekerja. Tipe kompensasi non finansial meliputi kepuasan yang didapat dari pelaksanaan tugas yang signifikan yang berhubungan dengan pekerjaan.

Pemberian kompensasi dalam suatu organisasi harus diatur sedemikian rupa sehingga merupakan sistem yang baik dalam organisasi (Simamora, 2006). Perusahaan memberikan kompensasi dengan harapan adanya rasa timbal balik dari karyawan tersebut untuk bekerja dengan prestasi yang baik. Hasibuan (2006) menyatakan bahwa kompensasi yang diterapkan dengan baik akan memberikan motivasi kerja bagi karyawan. Kompensasi yang diberikan harus layak, adil, dan dapat diterimakan, memuaskan, memberi motivasi kerja, bersifat penghargaan dan sesuai dengan kebutuhan (Lewa \& Subowo, 2005). Pemberian kompensasi akan memberikan manfaat kepada kedua belah pihak, baik kepada pihak perusahaan maupun kepada pihak karyawan.

Motivasi itu sendiri merupakan istilah lebih umum digunakan untuk mengantikan terma "motif-motif" yang dalam bahasa inggris yang disebut motive yang berasal dari kata motion, yang berarti gerakan atau sesuatu yang bergerak. Karna itu motivasi erat hubungan dengan gerak yang dilakukan manusia atau disebut perbuatan atau juga tingkah laku.

Peranan motivasi dalam kehidupan, Allah SWT berfirman dalam Al-Quran: "Sesungguhnya Allah tidak mengubah keadaan suatu kaum sehingga mereka mengubah keadaan yang ada pada diri mereka sendiri" (Ar-Ra'd: 11) . Dari ayat di atas kita bisa mengambil kesimpulan bahwa ternyata motivasi yang paling kuat adalah dari diri seseorang. Motivasi sangat berpengaruh dalam visi misi seseorang dalam setiap tindaktanduknya. Dalam kaitannya dengan tingkah laku keagamaan motivasi tersebut sangat penting, untuk dibicarakan dalam rangka mengetahui apa sebenarnya latar belakang suatu tingkah laku keagaman yang dikerjakan seseorang. Disini peranan motivasi itu sangat besar baik dalam bimbingan dan mengarahkan seseorang terhadap tingkah laku keagamaan. Namun demikian ada motivasi tertentu yang sebenarnya timbul dalam diri manusia disebabkan terbukanya hati manusia terhadap hidayah Allah SWT. Sehingga orang tersebut menjadi orang yang beriman dan kemudian dengan iman itulah ia lahirkan tingkah laku keagaman yang baik.

Mangkunegara (2001) menyatakan bahwa "kinerja adalah hasil kerja secara kualitas dan kuantitas yang dicapai seseorang karyawan dalam melaksanakan tugasnya sesuai dengan tanggung jawab yang diberikan kepadanya".

Menurut Hasibuan (2006), "kinerja karyawan adalah suatu hasil kerja yang dicapai seseorang dalam melaksanakan tugas-tugas yang dibebankan kepadanya didasarkan atas kecakapan, pengalaman dan kesungguhan serta waktu".

Mathis dan Jackson (2002) menyatakan bahwa "kinerja karyawan adalah apa yang dilakukan oleh seorang karyawan yang mempengaruhi seberapa banyak mereka memberi kontribusi kepada organisasi, yaitu dalam arti kualitas, kuantitas output, jangka waktu output, kehadiran di tempat kerja dan sikap kooperatif".

Dari pengertian-pengertian diatas maka penulis menarik kesimpulan bahwa kinerja karyawan adalah suatu tingkat kemampuan dan kemajuan seorang karyawan atas hasil kerja yang dilakukannya sehingga dapat memberikan kontribusi pada perusahaan yang berupa kualitas dan kuantitas kerja yang baik. 
Penilaian kinerja merupakan suatu proses organisasi untuk menilai kinerja pegawainya. Tujuan dilakukannya penilaian kinerja secara umum adalah untuk memberikan umpan balik kepada karyawan dalam upaya memperbaiki kinerjanya dan meningkatkan produktivitas organisasi, khususnya yang berkaitan dengan kebijaksanaan terhadap karyawan seperti untuk tujuan promosi, jabatan, kenaikan gaji, pendidikan dan latihan. Penilaian kinerja merupakan suatu kegiatan yang sangat berarti bagi organisasi. Organisasi haruslah memilih kriteria secara subjektif maupun objektif. Kriteria kinerja secara objektif adalah evaluasi kinerja terhadap standar-standar spesifik, sedangkan ukuran secara subyektif adalah seberapa baik seorang karyawan bekerja keseluruhan. Penilaian kinerja (performance appraisal) adalah proses evaluasi seberapa baik karyawan mengerjakan, ketika dibandingkan dengan satu set standar dan kemudian mengkomunikasikannya dengan para karyawan (Mathis dan Jackson, 2002). Penilaian kinerja disebut juga sebagai penilaian karyawan, evaluasi karyawan, tinjauan kinerja, evaluasi kinerja dan penilaian hasil pedoman.

Penilaian kinerja menurut Armstrong dan Baron (1998) adalah sebagai berikut: (1) Ukuran dihubungkan dengan hasil, (2) Hasil harus dapat dikontrol oleh pemilik pekerjaan, (3) Ukuran objektif dan observable, (4) Data harus dapat diukur, (5) Ukuran dapat digunakan di manapun. Penilaian kinerja merupakan landasan penilaian kegiatan manajemen sumber daya manusia seperti perekrutan, seleksi, penempatan, pelatihan penggajian, dan pengembangan karir.

Penilaian kinerja dapat terjadi dalam dua cara, secara informal dan secara sistimatis (Mathis dan Jackson, 2002). Penilaian informal dapat dilaksanakan setiap waktu di mana pihak atasan merasa perlu. Sedangkan hubungan sehari-hari antara manajer dan karyawan memberikan kesempatan bagi kinerja karyawan untuk dinilai. Penilaian sistimatis akan digunakan ketika kontak antara manajer dan karyawan bersifat formal, dan sistemnya digunakan secara benar dengan melaporkan kesan dan observasi manajerial terhadap kinerja karyawan.

Menurut Mangkunegara (2001), menyatakan "faktor-faktor penilaian kerja terdiri atas 4 (empat) aspek, yaitu: (1). Hasil kerja, yaitu keberhasilan karyawan dalam pelaksanaan kerja (output) biasanya terukur, seberapa besar yang telah dihasilkan, berapa jumlahnya. dan berapa besar kenaikannya, misalnya omset pemasaran, jumlah keuntungan dan total perputaran asset, (2). Perilaku, yaitu aspek tindak tanduk karyawan dalam melaksanakan pekerjaan, pelayanan, kesopanan, sikap dan perilakunya baik terhadap sesama karyawan maupun kepada atasan, (3). Atribut dan kompetensi, yaitu kemahiran dan pengusaaan karyawan sesuai tuntutan jabatan, pengetahuan, kemitraan dan keahlian. (4). Komparatif, yaitu membandingkan hasil kinerja karyawan dengan karyawan lainnya yang selevel dengan karyawan yang bersangkutan, misalnnya sesama sales berapa omset penjualannya selama satu tahun.

Dari uraian di atas dapat disimpulkan bahwa penilaian kinerja merupakan bagian integral dari proses penilaian yang meliputi: penerapan sasaran kinerja yang spesifik, terukur, memiliki tingkat perubahan, terbatas waktu, adanya pengarahan dan dukungan atasan. Karyawan bersama atasan masingmasing dapat menetapkan sasaran dan standar kinerja yang harus dicapai dalam kurun waktu tertentu. Peningkatan kinerja seorang karyawan pada gilirannya akan mendorong kinerja sumber daya manusia secara keseluruhan. Penilaian kinerja adalah penilaian tentang prestasi kerja 
karyawan dan penilaian kerja sangat penting bagi manajemen untuk digunakan dalam menjelaskan tujuan dan standart kerja.

\section{METODE PENELITIAN}

Penelitian ini menggunakan pendekatan kuantitatif, metode survey dan teknik analisis jalur. Data dikumpulkan menggunakan instrumen dalam bentuk kuesioner. Instrumen dikalibrasi menggunakan validitas item dan koefisien keandalan. Data dianalisis menggunakan Structural Equation Modeling (SEM) dengan paket PLS Smart.

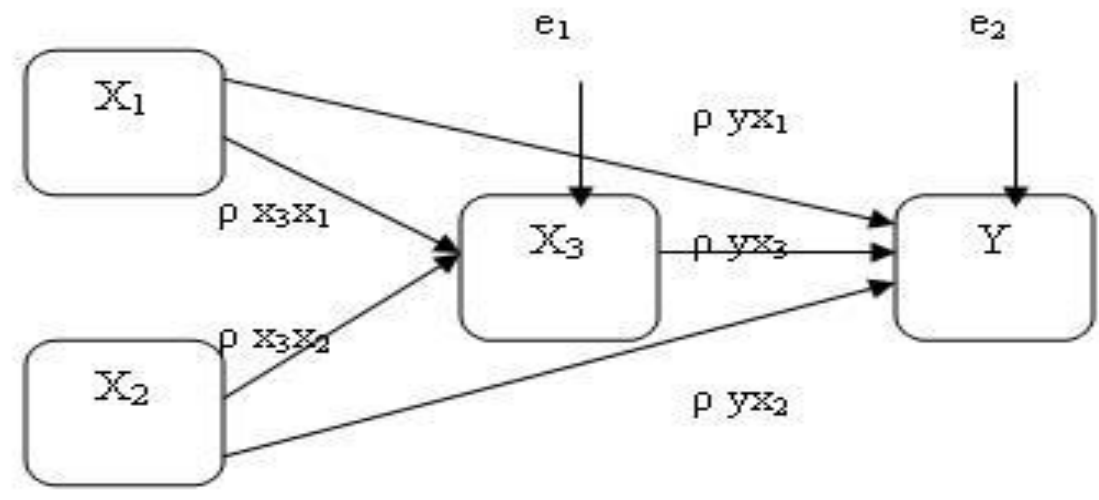

Gambar 1. Model Kontelasi Penelitian

\section{Keterangan :}

$\mathbf{X}_{\mathbf{1}}=$ Kepemimpinan Islami

$\mathrm{X}_{2}=$ Kompensasi Finansial

$\mathrm{X}_{3}=$ Motivasi Kerja

$\mathrm{Y}=$ Kinerja

Populasi dalam penelitian ini adalah para dosen di Universitas Djuanda Bogor, ada 14 Prodi masing masing prodi diambil 11 dosen sehingga 14 prodi x 11 dosen $=154$ dosen secara acak. Berdasarkan kriteria yang ditentukan peneliti, maka anggota populasi sejumlah 154 dosen, sedangkan responden yang digunakan sebagai sampel menggunakan rumus yang dikemukakan Slovin yaitu Besarnya sampel dalam penelitian ini ditentukan dengan rumus Slovin sebagai berikut:

$n=\frac{N}{1+N \cdot e^{2}}$

Rumus Slovin untuk menentukan sampel adalah :

Dimana:

$n=$ jumlah elemen / anggota sampel

$\mathrm{N}=$ jumlah elemen / anggota populasi

$$
\begin{aligned}
& \mathrm{e}=\text { error level (tingkat kesalahan } 5 \%) \\
& n=\frac{154}{\left(154 \times 0,05^{2}\right)+1} \\
& n=\frac{154}{(154 \times 0,0025)+1} \\
& n=\frac{154}{(0,385)+1} \\
& n=\frac{154}{1,385} \\
& n=111,19
\end{aligned}
$$

Jumlah sampel dalam penelitian ini sebanyak 111 dosen.

Pengumpulan data dilakukan dengan menyebarkan kuesioner ke para responden. Kuesioner terdiri dari 4 variabel, yaitu: 1). Variabel Kepemimpinan Islami dengan 6 item pertanyaan, 2). Variabel Kompensasi Finansial dengan 7 item, 3). Variabel Motivasi kerja dengan 8 item, dan 4). Variabel Kinerja dosen sejumlah 8 item. Masing-masing item tersebut 
menggunakan skala lickert dengan rentang jawaban 1 sampai 5.

\section{HASIL DAN PEMBAHASAN}

Teknik analisis data dalam penelitian ini menggunakan SPSS untuk pengujian kuesioner yaitu uji validitas dan reliabilitas, sedangkan untuk menguji pengaruh masing-masing variabel menggunakan Structural Equation Modeling (SEM) dengan paket Smart $P L S$. Uji validitas dilakukan dengan melihat nilai loading factor masingmasing indikator yang ada di 4 variabel yang diteliti di Universitas Djuanda, hasil menunjukkan bahwa nilai loading factor dari masing-masing indikator tersebut diatas 0,5 dengan tingkat signifikansi 5\%, hal ini menujukkan bahwa masing- masing indikator adalah valid (construct validity, alat ukur terpenuhi). Sedangkan untuk Uji Reliabilitas menggunakan nilai composite variable dengan ketentuan besarnya dari nilai tersebut harus lebih besar dari 0,6 (composite reliability > 0,6). Hasil uji reliabilitas menunjukkan bahwa masing-masing variabel mempunyai nilai composite variable diatas 0,6 , sehingga dapat diberikan kesimpulan bahwa seluruh indikator/alat ukur adalah relialibel dan dapat digunakan untuk analisa selanjutnya.

Pengujian selanjutnya dilakukan untuk mengetahui apakah ada pengaruh antar variabel laten yang telah di hipotesiskan sebelumnya. Hasil pengujian dapat dilihat pada tabel di bawah ini.

Tabel 1. Koefisien Jalur Regresi

\begin{tabular}{llll}
\hline No Variabel & \multicolumn{2}{c}{$\begin{array}{c}\text { Regression } \\
\text { Weight } \\
\text { (Standardized) }\end{array}$} & $\begin{array}{c}\text { K-Statistic(T-Statistic } \\
\text { >1,96) }\end{array}$ \\
\hline $1 . \mathrm{X} 1 \rightarrow \mathrm{X} 3$ & 0,489 & 3,753 & Signifikan \\
2. X2 $\rightarrow$ X3 & 0,061 & 0,284 & Tidak \\
& & & Signifikan \\
3. X1 $\rightarrow$ Y & $-0,155$ & 0,793 & Tidak Signifikan \\
4. X2 $\rightarrow$ Y & 0,296 & 2,624 & Signifikan \\
5. X3 $\rightarrow$ Y & 0,541 & 4,294 & Signifikan \\
\hline
\end{tabular}

Sumber: Hasil Olahan PLS (2020)

\section{Keterangan :}

$\mathrm{X} 1$ : Kepemimpinan Islami

X2 : Kompensasi Finansial

X3 : Motivasi Kerja

Y : Kinerja dosen

Pengujian hipotesis dilakukan dengan membandingkan nilai t-statistik pada setiap variabel laten dengan t-tabel $(1,96)$, yaitu dikatakan signifikan jika tstatistik variabel laten lebih besar dari 1,96 .

Setelah dilakukan penelitian dan menganalisa data yang didapat dari responden untuk menguji hipotesis, maka hasil penelitian dapat dijabarkan berikut:
1. Hipotesis 1 didukung oleh hasil penelitian, yaitu kepemimpinan Islami $\left(\mathrm{X}_{1}\right)$ secara signifikan mempengaruhi motivasi kerja $\left(\mathrm{X}_{3}\right)$, hal ini didukung dengan nilai t-statistic diatas 1,96 yaitu sebesar 3,653. Hasil ini mendukung teori maupun penelitian terdahulu.

2. Hasil pengujian menunjukkan bahwa variabel bebas kompensasi finansial $\left(\mathrm{X}_{2}\right)$ tidak berpengaruh terhadap motivasi kerja $\left(\mathrm{X}_{3}\right)$, hal ini ditunjukkan dengan nilai t-statistik sebesar 0,283, dimana nilai ini dibawah nilai t-tabel $(1,96)$. Hasil penelitian ini menolak atau tidak mendukung hipotesis 2 . 
3. Hasil penelitian tidak mendukung hipotesis 3, karena nilai t-statistic sebesar 0,793 dibawah t- tabel $(1,96)$, hal ini berarti bahwa kompensasi finansial $\left(\mathrm{X}_{2}\right)$ tidak mempengaruhi kinerja dosen $(\mathrm{Y})$.

4. Hasil penelitian mendukung hipotesis 4, yaitu kepemimpinan Islami $\left(\mathrm{X}_{1}\right)$ secara signifikan mempengaruhi kinerja dosen $(\mathrm{Y})$ dengan nilai $\mathrm{t}$ statistic diatas t-tabel $(1,96)$ yaitu sebesar 2,624.

5. Motivasi Kerja $\left(X_{3}\right)$ secara signifikan mempengaruhi Kinerja Karyawan (Y) dengan nilai t- statistic 4,294, hasil ini mendukung pernyataan. yang diungkap di hipotesis 5 .

6. Terkait dengan hasil penelitian untuk hipotesis 2 dan hipotesis 3 yang menunjukkan bahwa kompensasi finansial tidak berpengaruh terhadap motivasi kerja maupun kinerja dosen, hal ini dapat terjadi kemungkinan disebabkan karena responden yang dipilih para dosen yang berada di tingkat menengah keatas, sehingga dalam kondisi seperti ini, harapan dari masing-masing responden bukan semata-mata kompensasi finansial yang dituju melainkan pengabdian dosen untuk memberikan yang terbaik kepada Perguruan Tinggi Universitas Djuanda hanya mencari ridho Allah SWT, ini dapat menjadi pertimbangan dalam meningkatkan motivasi maupun kinerja dosen, karena pada umumnya kompensasi finansial yang diterima para responden sesuai yang diharapkan.

\section{KESIMPULAN}

Penelitian ini ditujukan untuk menguji pengaruh kepemimpinan Islami, kompensasi finansial, dan motivasi terhadap kinerja dosen. Penelitian dilakukan dengan menggunakan 111 responden yang berasal dari dosen Universitas Djuanda dari 14 Program Studi dan setiap Prodi diambil 11 dosen secara acak yang bekerja di Universitas Djuanda Bogor yang ada di wilayah Provinsi Jawa Barat. Hasil penelitian menunjukkan bahwa kompensasi finansial tidak mempengaruhi motivasi kerja maupun kinerja dosen di Universitas Djuanda Bogor. Sedangkan kepemimpinan Islami secara signifikan mempengaruhi motivasi kerja maupun kinerja dosen, dan motivasi kerja secara signifikan mempengaruhi kinerja dosen.

\section{DAFTAR PUSTAKA}

Abdul Jawwad, Muhammad. 2009. Rahasia Sukses Manajemen Rosululloh. Ziyad Visi Media. Surakarta.

Armstrong, M. and Baron, A. 1998. Performance Management - The New Realities. Institute of Personnel and Development. London.

Bastoni, Hepi Andi. 2006. 101 Kisah Tabi'in, cet. ke-1. Pustaka. Jakarta.

Davis, Keith. 1985. Perilaku Dalam Organisasi. Erlangga. Jakarta.

Griffin, Ricky, W. \& Ronald, J. Ebert. 1998. Bisnis. Prenhallindo. edisi bahasa Indonesia. Jakarta.

Hafidhuddin, Didin dan Tanjung, Hendri. 2003. Manajemen Syari'ah dalam Praktik. Gema Insani. Jakarta.

Handoko, T. Hani. 2001. Manajemen Personalia dan Sumber Daya Manusia. Penerbit Andi. Yogyakarta.

Hasibuan, Malayu S.P. 2006. Manajemen Sumber Daya Manusia. PT Haji Masagung. Jakarta.

Lewa dan Subowo. 2005. Pengaruh Kepemimpinan, Lingkungan Kerja Fisik Dan Kompensasi Terhadap 
2020, Jurnal Tabarru' : Islamic Banking and Finance 3 (2) : 118 - 127

Kinerja Karyawan Di PT.

Pertamina (Persero) Daerah

Operasi Hulu Jawa Bagian Barat,

Cirebon. Jurnal Sinergi. Edisi

Khusus on Human resource, Hal $129-140$.

Mangkunegara, Anwar A.A.

2001. Manajemen Sumber

Daya Manusia Perusahaan. PT.

Remaja Rosdakarya. Bandung.

Mathis, Robert L. dan Jackson, John H. 2002. Manajemen Sumber Daya Manusia. Salemba Empat. Jakarta.

Simamora, Henry. 2006. Manajemen Sumber Daya Manusia, edisi ketiga, Cetakan kedua. Penerbit STIE YKPN. Yogyakarta.

William, Lindsay M. dan Patrick, A. Joseph. 1997. Total Quality and Organization Development. St.LuciePress. Florida. 